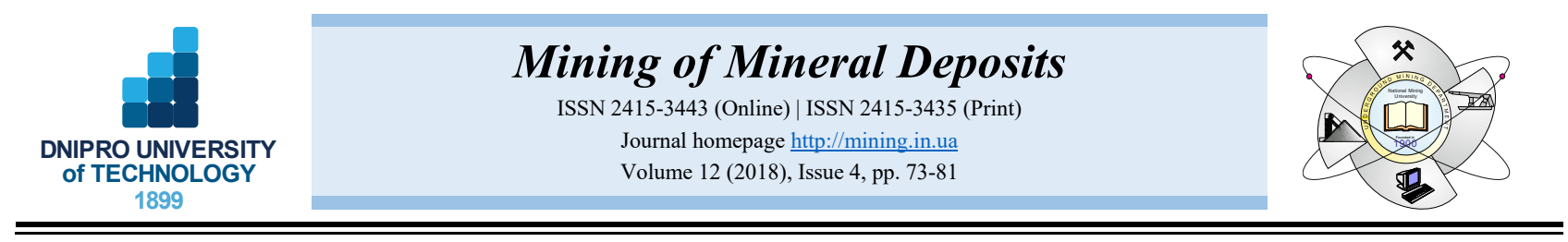

UDC 622.023 .23

https://doi.org/10.15407/mining12.04.073

\title{
EVALUATION OF VOLUMETRIC STRAIN QUANTITIES \\ AND TYPES OF VOLUMETRIC STRAIN CURVES UNDER FAILURE-DEFORMATION PROCESS OF HARD BRITTLE ROCKS
}

\author{
V.A. Akinbinu ${ }^{1 *}$, E.O. Ajaka ${ }^{1}$, D.J. Afu ${ }^{1}$ \\ ${ }^{I}$ Federal University of Technology Akure, Akure, Nigeria \\ *Corresponding author: e-mail akinbinuvictor@gmail.com,tel.+2348038520736
}

\begin{abstract}
Purpose. The aim of this work is to show whether or not a relationship exist among the different volumetric strain quantities and to assess also whether the volumetric quantities are related to the different types of volumetric strain curves under failure-deformation process of hard brittle rocks.
\end{abstract}

Methods. Tests were conducted to determine the post failure stress-strain curves of different 83 rocks types under uniaxial compression using a closed loop servo-controlled testing system in accordance to ISRM (International Society for Rock Mechanics) suggested standards.

Findings. The result show that the volumetric strains quantities are related by power form law. It was established that there is a connection between the volumetric strains quantities and the types of the volumetric strains curves. The first type volumetric strain curves contains the Class I and progress to Class II while the type three volumetric strain curves are entirely Class II rock.

Originality. No experimental results have been published, which describe the connection between the type of volumetric strain curves and volumetric strain quantities or attempt to relate the volumetric strain quantities with type of post-failure stress-strain characteristic curves response of rocks under uniaxial compression. Most researchers in rock mechanics studies have so far been focused on the crack damage stress $\left(\sigma_{c d}\right)$ and uniaxial compressive strength $\left(\sigma_{c}\right)$ of characteristic stress levels during compression in which $\sigma_{c d}=\varepsilon_{c d}$ and $\sigma_{c d}=\sigma_{c}$ to study deformation behavior of rocks.

Practical implications. It was also observed that the difficulty in obtaining the post-failure curves increases from type one to type two and type three volumetric strain curves respectively. It could guide personnel conducting tests using closedloop servo-controlled testing system, if dangerous situation or equipment damage could occur (especially with the third type deformation process) so that testing is performed safely. It could also be useful in understand-ding the total process of specimen deformation and estimation of the rocks brittleness (e.g. brittle for Class II and less brittle or ductile for Class I).

Keywords: post-failure curves, deformation process, elastic volumetric strain, volumetric slope, maximum total volumetric strain, brittle rocks

\section{INTRODUCTION AND BRIEF LITERATURE REVIEW}

Deformation and fracture characteristics of brittle rocks have been studied by earlier researchers (Bieniawski, 1967b; Wawersik \& Fairhurst, 1970; Martin \& Chandler, 1994). The common agreement among them was that the failure process occurs in stages. The stages were determined from stress-strain characteristic curves obtained from axial and lateral deformation measurements during laboratory uniaxial compression test. Brace, Paulding, \& Scholz (1966) and Bieniawski (1967a) evaluated stress-strain behaviour of a deformed material and classified the deformation steps in the brittle fracture process (Fig. 1) as follows:

- closing of cracks (or crack closure) (stage I);

- linear elastic deformation (or fracture initiation) (stage II);

- stable fracture propagation (or critical energy release) (stage III);

- unstable fracture propagation (or material failure) (stage IV).

After stage IV is reached sophisticated procedure is needed to obtain further information on the post-failure characteristic behaviour of the stress-strain curves.

(C) 2018. V.A. Akinbinu, E.O. Ajaka, D.J. Afu. Published by the Dnipro University of Technology on behalf of Mining of Mineral Deposits.

This is an Open Access article distributed under the terms of the Creative Commons Attribution License (http://creativecommons.org/licenses/by/4.0/),

which permits unrestricted reuse, distribution, and reproduction in any medium, provided the original work is properly cited. 


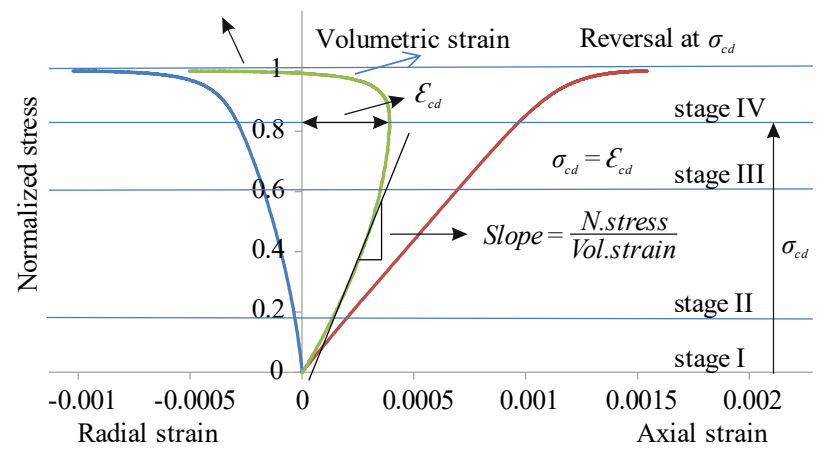

Figure 1. Normalized stress-strain curves, marble specimen for type 1 volumetric strain curves

In order to achieve this closed loop servo-controlled testing system is used using output of the lateral strain as the feedback signal. The post-failure regime is shown in Figure 2.

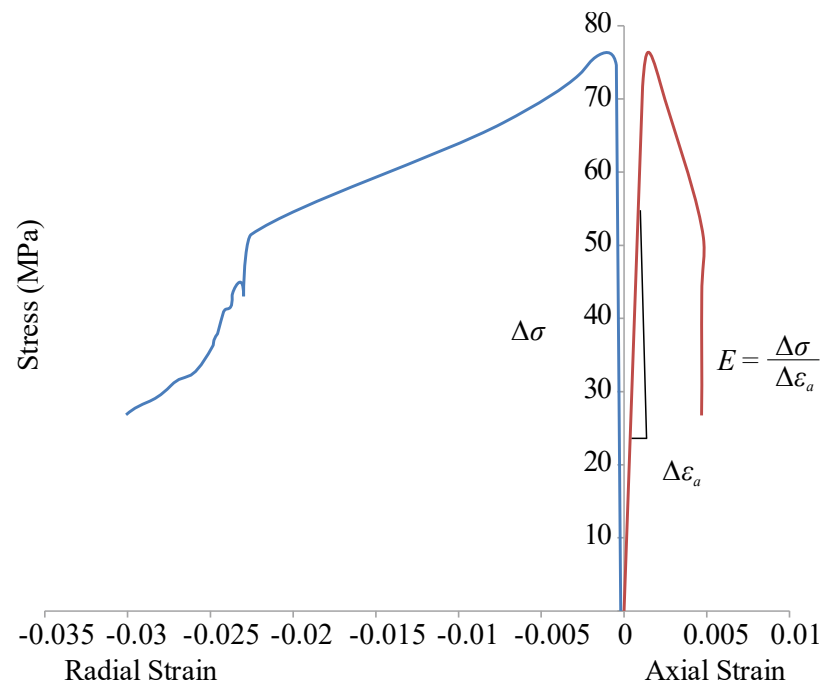

Figure 2. Post-failure stress-strain curves, marble specimen

Crack closure occurs during the early stage of loading (crack closure corresponds to stage I, Figure 1). At this stage, the stress-strain curve is slightly inclined towards the axial strain. As a result, the pre-existing cracks inclined to the applied load are closed (Eberhardt, Stead, \& Szczepanik, 1998). At the crack closure stage, the stress-strain curve is nonlinear and expresses an increase in axial stiffness (i.e. deformation modulus). The size of this nonlinearity depends "on the initial crack density and geometrical characteristics of the crack population" (Eberhardt, Stead, \& Szczepanik, 1998). After the pre-existing cracks are closed, linear elastic deformation takes place.

Unstable crack growth occurs at the point of reversal of the volumetric strain curve (stage III, Figure 1). This stage is known as the point of critical energy release or crack damaged stress threshold (Martin, 1993). Bieniawski (1967c) defined unstable crack propagation as the condition which occurs when the relationship between the applied stress and the crack length ceases to exist. Therefore, this is when the crack growth velocity, takes over in the propagation process. The velocity of the crack propagation increases from stage III and reaches its maximum (terminal velocity) (Eq. 1) at stage IV: $v_{t}=0.38 \sqrt{\frac{E}{\rho}}$,

where:

$E$ - the elastic modulus and $\mathrm{p}$ is the density of the rock specimen.

In the opinion of Craggs (1960), as crack velocity increases, the force needed to uphold crack propagation decreases. Unstable fracture propagation starts when the strain energy release rate attains a critical value (Kemeny $\&$ Cook, 1986). The cracks continue to extend because of the strain energy stored within the specimen.

The generation of cracks will lead to increase in the volume of rocks. For that reason, the change in volume signifies the extent in which the rock specimens are damaged (Qiaoxing, 2006). Therefore, it can be implicitly said that the volume change is related to the damage. Many researchers have endeavored to compare the degree of damage to the change of the inelastic volumetric strain (Eberhardt, Stead, \& Szczepanik, 1998; Lau \& Chandler, 2004; Pérez Hidalgo \& Nordlund, 2013). Martin (1993) described the inelastic volumetric strain as the crack volumetric strain that is attributed to axial cracking and proposed using the calculated crack volumetric strain to identify crack initiation. The calculated crack volumetric strain is the difference between the total volumetric strain (i.e. $\varepsilon_{a}+2 \varepsilon_{r}$ ) and the elastic volumetric strain. Expression in Equation 2 is used to estimate the elastic volumetric strain:

$\varepsilon_{c r}=\left(1-\frac{2 v}{E}\right) \cdot \sigma$

where:

$v$ - Poisson's ratio;

$E$ - modulus of elasticity and $\sigma$ is the axial stress.

Kim, Lee, Cho, Choi, \& Cho (2015) observed that most of the damage (about $78 \%$ of the total damage) occurred after the crack damage stress. They found that the unstable crack propagation and crack coalescence played a much larger role than initiation of new cracks and stable crack growth in the development of significant damage in rock. They assumed that damage accumulation does not occur below the crack initiation stress threshold. This position was based on the fact that damage does not accumulate in an elastic region of a material, that is, between crack closure and crack initiation.

The crack damage stress $\sigma_{c d}$ is the stress level at which the maximum total volumetric strain is attained (Palchik \& Hatzor, 2002). Therefore, at the point of crack damage stress $\sigma_{c d}$ the maximum total volumetric strain is attained (i.e. $\sigma_{c d}=\varepsilon_{c d}$ ). The point at which $\sigma_{c d}=\varepsilon_{c d}$ defines the type one and type two volumetric strain curves in which type one has negative total volumetric strain (Figure 1 with the post-failure characteristic curves shown in Figure 2) and type two with positive total volumetric strain (Figure 3 with the post-failure characteristic curves shown in Figure 4). The type one and type two volumetric strain curves have reversal at crack damage stress level $\sigma_{c d}$. 


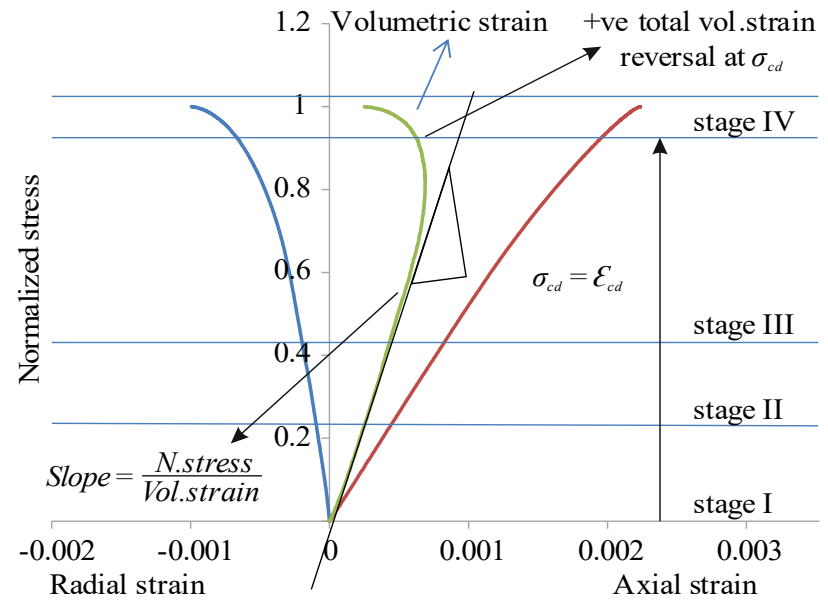

Figure 3. Normalized stress-strain curves, troctolite specimen for type 2 volumetric strain curves

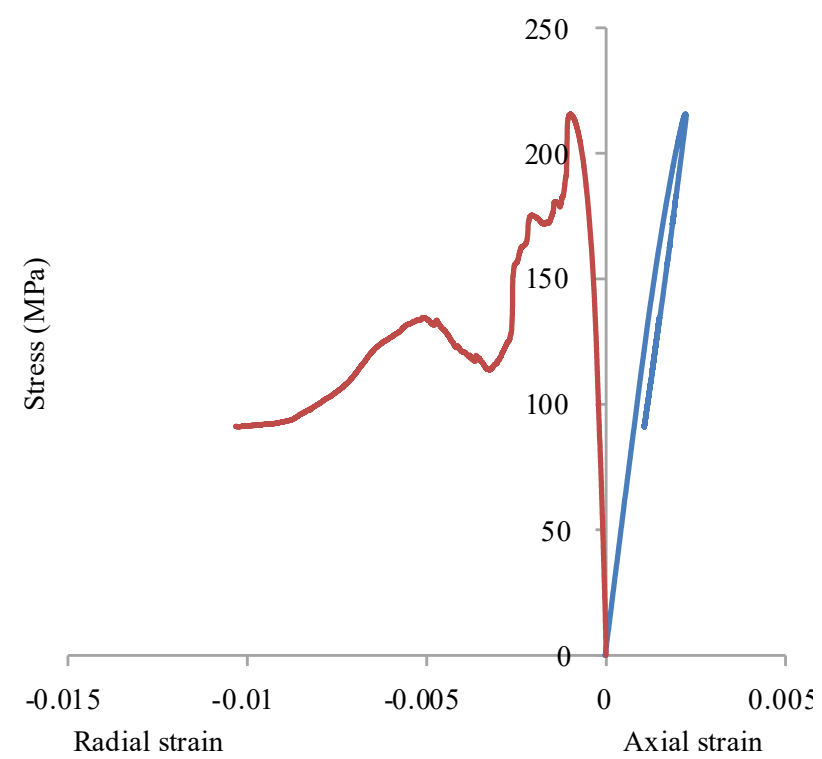

Figure 4. Post-failure stress-strain curves, troctolite specimen

When the maximum total volumetric strain is attained at the uniaxial compressive strength of the rocks, $\sigma_{c}$ (i.e. $\sigma_{c d}=\sigma_{c}$ ) define the type 3 volumetric strain curve. In this case, the bulk volume of rock decreases until failure occurs (Figure 5 with the post-failure characteristic curve shown in Figure 6).

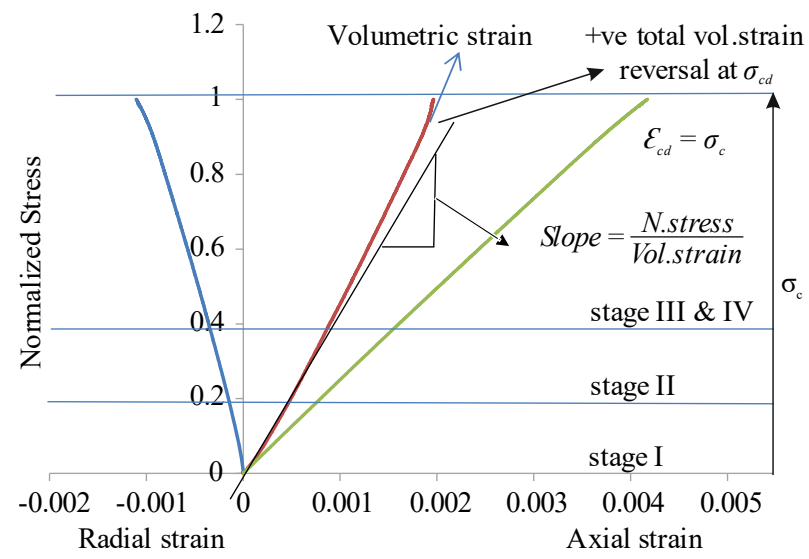

Figure 5. Normalized stress-strain curves, quartzite 2 specimen for type 3 volumetric strain curves

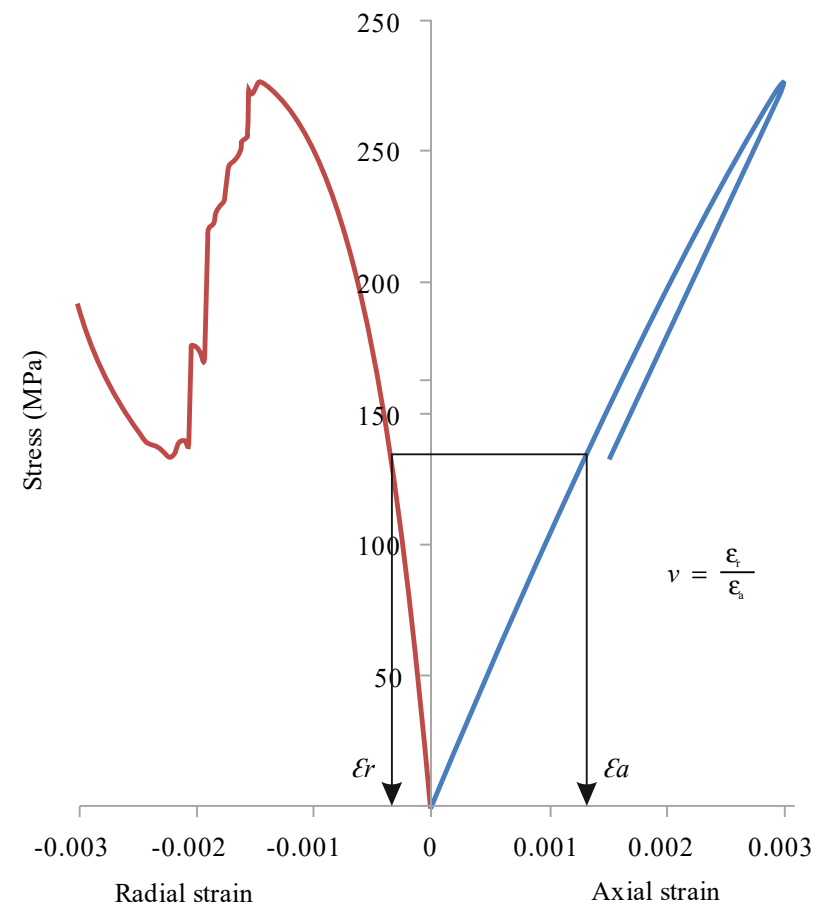

Figure 6. Post-failure stress-strain curves, quartzite 2 specimen

Most researchers in rock mechanics studies have so far been focused on the crack damage stress $\left(\sigma_{c d}\right)$ and uniaxial compressive strength $\left(\sigma_{c}\right)$ of characteristic stress levels during compression in which $\sigma_{c d}=\mathcal{E}_{c d}$ and $\sigma_{c d}=\sigma_{c}$ to evaluate damage in rocks (e.g. Palchik \& Hatzor, 2002; Cai et al., 2004; Katz \& Reches, 2004; Palchik, 2009; Stefanov, Chertov, Aidagulov, \& Myasnikov, 2011). This work will evaluate different types of volumetric strain quantities and their relationships. It will also evaluate their relationships for different groups of volumetric strain curves types. This work will attempt to provide answers to the following questions. Is there a connection among the volumetric strain quantities? Is the volumetric strain quantities related to the types of the volumetric strain curves? Which type(s) of volumetric strain curve(s) are more connected or can be linked with the type of post-failure stress-strain characteristic curves response (class I or class II)? To the author's knowledge, so far no experimental results have been published, which describe the connection between the type of volumetric strain curves and volumetric strain quantities or attempt to relate the volumetric strain quantities with type of post-failure stress-strain characteristic curves response of rocks under uniaxial compression.

\section{METHOD}

Complete stress-strain curves were determined under unconfined uniaxial compression test using a closed loop servo-controlled testing system in order to estimate the mechanical properties of 83 different rocks types from different origins (53 igneous, 10 sedimentary and 20 metamorphic). The testing procedures for the determination of complete stress-strain curves of the rocks have been done according to ISRM suggested method (Ulusay, 2015). The strength parameters were estimated according to ISRM suggested methods (Ulusay, 2015). In 
this case the uniaxial compression strength (UCS) is the stress level at specimen failure load. The elastic modulus, $E$, is estimated as the average modulus of the slope of linear portion of axial stress-strain curves (this is estimated at about 30 to $70 \%$ at the axial stress level) (Fig. 2). The Poisson's ratio, $v$, is calculated as the ratio of radial strain to axial strain at $50 \%$ axial stress level (Fig. 6). Five tests were performed for each rock type and the average value calculated.

The stress-strain curves were determined for the different 83 rocks types with UCS ranging from $640.9 \mathrm{MPa}$ to $43.7 \mathrm{MPa}$ with an average value of $216.1 \mathrm{MPa}$ and $E$ ranging from $150 \mathrm{GPa}$ to $25 \mathrm{GPa}$ with an average value of $69 \mathrm{GPa}$; and $v$ ranging from 0.4108 to 0.0824 with an average value of 0.2315 . The post-failure moduli were used to characterise the rocks as Class I for negative sign modulus and Class II for positive sign modulus. How the post-failure moduli were estimated from the stress-strain curves has been described elsewhere (Akinbinu, 2017). The characteristic behaviour of Class I and Class II rocks and their response under axial loading condition has been described by Akinbinu (2016).

Stress-axial, radial and total volumetric strain curves for the various brittle rocks up to strength failure were constructed according to Martin and Chandler (1994) and Bieniawski (1967a) to show the stages in the deformation process and were grouped into the different volumetric strain curves types (types $1-3$ ). The quantities relating to the volumetric strain curve which include the maximum total volumetric strain $\underline{\varepsilon}_{\underline{c} d}$ and elastic volumetric strain were estimated to represent volumetric quantities of the failure-deformation process of the brittle rocks. In this study the slope of total volumetric strain and normalized axial stress curve is also evaluated to represent volumetric quantity of the deformation process. The slope of the curves were determined from the linear part of total volumetric strain and normalized axial stress curves such that a tangent is drawn parallel to the linear elastic deformation stage (i.e. from end of crack closure to the end of linear elastic deformation stage, see Figures $1,3,5)$. It can be defined as the total volumetric strain per unit normalised stress.

The volumetric strain quantities were compared with each other in order to see if there exists a connection between them. The quantities were also compared for each type of the volumetric strain curves grouped as type one, type two and type three respectively. These deformation process types or the types of volumetric strain curves were also compared with shapes of the postfailure regime linked to the difficulty in obtaining it. The approach was to find out if the volumetric strain quantities are related to each other, whether the quantities are related to the types of volumetric curves and what effect the volumetric strain quantities have on the characteristic shapes of the post-failure curves.

\section{RESULTS AND DISCUSSION}

The author use of crack damage stress $\left(\sigma_{c d}\right)$ and maximum total volumetric strain $\left(\varepsilon_{c d}\right)$ in which $\sigma_{c d}=\varepsilon_{c d}$ to characterise volumetric strain curves from normalised pre-failure stress-strain curves has enables to divide the type one volumetric strain curve into two types. The first type has a negative total volumetric strain and with a point of reversal at crack damage stress. The second type has positive total volumetric strain with reversal point at crack-damaged stress. For rocks that exhibited the first type of deformation process, the volumetric strain curve is shown in Figure 1 while post-failure characteristic curves is shown in Figure 2 as an example for the type. The post-failure stress-strain curves for this type of rocks are relatively easy to perform. The type 2 volumetric strain curve is shown in Figure 3 and characteristic post-failure stress-strain curve is shown in Figure 4 as an example for the second type. For the second type volumetric strain curve, the process of unstable crack propagation (stage IV) has a small duration. Thus, the rocks exhi-bited a higher velocity of microcracks propagation. This made it difficult to control the post-failure curves than the type one volumetric strain curves because of the short duration of the crack damage stress threshold to rupture.

For the third type of volumetric strain curves, the crack induced stress and the structural failure of the rock specimen occurred together (Fig. 5) with characteristic post-failure stress-strain curve shown in Figure 6. There was no reversal of the total volumetric strain so there was continued decrease in rock volume. The control feedback, the circumferential strain, does not continuously increase with the applied load after the peak load. Instead, the deformation became selfsustaining and as a result the microcracking of the material continued on its own accord.

Furthermore, unstable crack growth occurs at the onset of the crack initiation stress for the third type volumetric strain curve. The critical energy release rate or crack damage stress threshold started much earlier for this type of curve than observed with others. Under this condition, the relationship between the applied stress and the crack length ceases to exist and other parameters, such as the crack growth velocity (as described in Equation 1), take control of the propagation process. These specimens exhibit high microcracking propagation velocity. The cracks continued to extend because the elastic strain energy stored within the specimen is released. The elastic strain energy accumulated in the system during loading and available for rupture development in the post-failure region was higher than the work that the specimen can do at the post-failure phase.

The difficulty in obtaining the post-failure curves increases as the total volumetric strain approaches a positive value. In other words, difficulty in obtaining the post-failure curves increases from the first type to the second type and finally the third type volumetric strain curves. For the first and second types, the four stages of deformation process are identifiable while only three stages of deformation process are identifiable with the third type (Figs. 1, 3, 5). The first type deformation process contains the Class I while the second and third types show entirely Class II characteristic behaviour.

The volumetric strain quantities were compared with each other. The comparisons show that there exists a relationship among the volumetric strain quantities (Figs. $7-9$ ). 


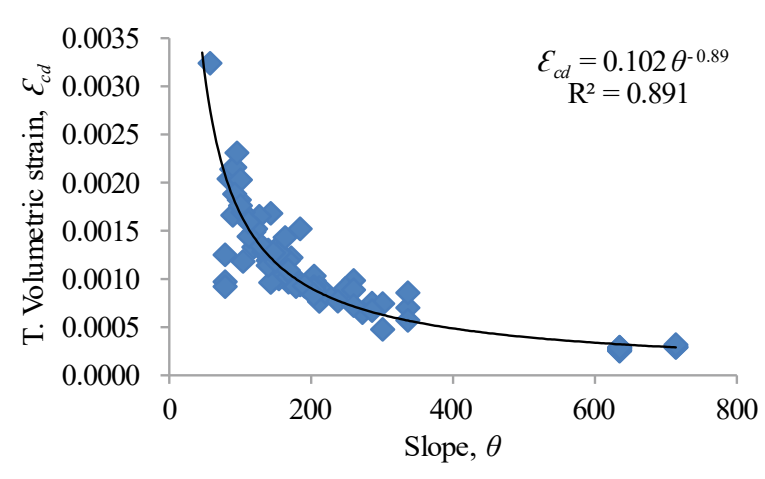

Figure 7. Maximum total volumetric strain and slope for combined sample

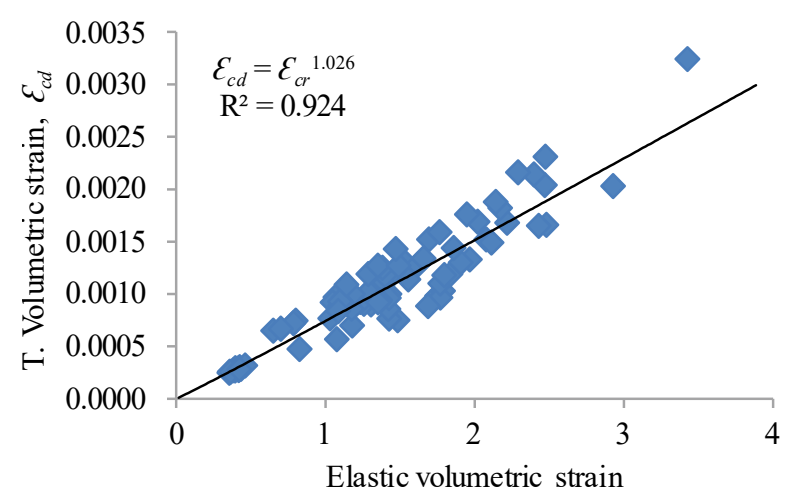

Figure 8. Maximum total volumetric strain and calculated volumetric crack for combined sample

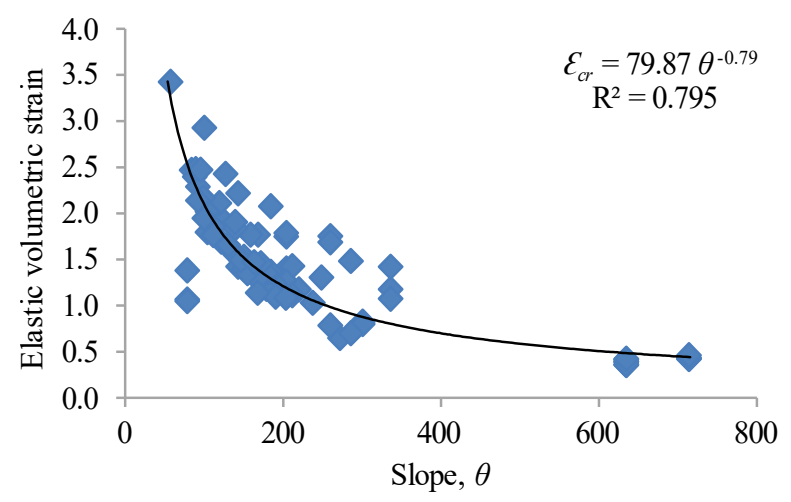

Figure 9. Elastic volumetric strain and slope for combined sample

The volumetric strain quantities are related with each other by power form law and can be expressed as $\varepsilon_{c d}=k \theta^{-n}$ and $\varepsilon_{c d}=\varepsilon_{c r}{ }^{n}$ and $\varepsilon_{c r}=k \theta^{-n}$ power form functions in which $\mathrm{k}$ and $\mathrm{n}$ can be termed as volumetric strain constants and exponents. The correlation coefficients of maximum total volumetric strain with slope of the normalised stress-total volumetric strain and with the elastic volumetric strain are significant, 0.89 and 0.92 respectively. These strong correlation coefficients simply show that these quantities are connected with each other and therefore are mathematically related by power form law. Similarly the elastic volumetric strain correlated with the slope of normalised stress-total volumetric strain curve with a coefficient of correlation of 0.79 . The relationship of maximum total volumetric strain with the slope of the normalised stress-total volumetric strain curve can better be described as $\varepsilon_{c d}=0.102 / \theta^{0.89}$.
This is to say that as the slope of the normalised stress-total volumetric strain curve increases, the maximum total volumetric strain decay (decrease) by power of 0.89 of the slope of normalised stress-total volumetric strain curve. The relationship of maximum total volumetric strain with elastic volumetric strain can be expressed by the power form law $\varepsilon_{c d}=\varepsilon_{c r}^{1.026}$. So, as the elastic volumetric strain increases the maximum total volumetric strain increases by 1.026 power form of the elastic volumetric strain.

In addition the volumetric strain quantities were coordinated such that the quantities were compared for each group of the different types of volumetric strain curves. The volumetric strain quantities show relationships with the different groups of the types of volumetric strain curves. The maximum total volumetric strain is related with the slope of normalised stress-total volumetric strain curve for each group of the different types of volumetric strain curves by power form function. The curvature of the concave curve get deeper and closer to the $X-Y$ axis as the volumetric strain curves changes from type one to type two and type three respectively (Figs. $10-12$ ).

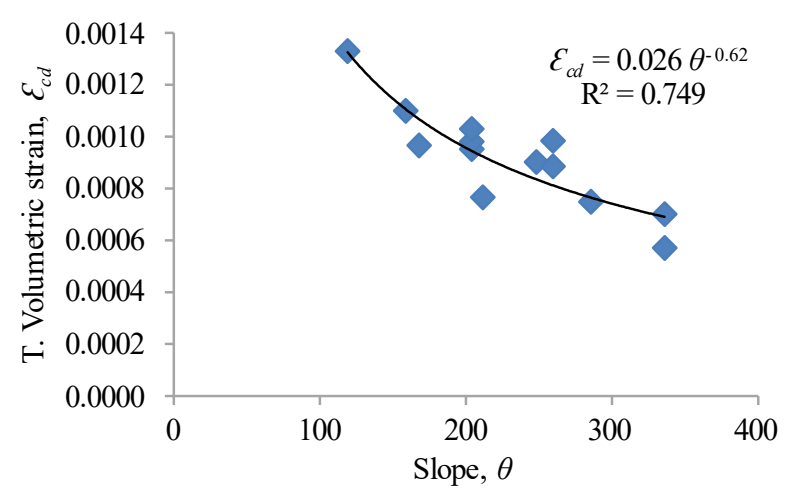

Figure. 10 Maximum total volumetric strain and slope for type 1 volumetric strain curve

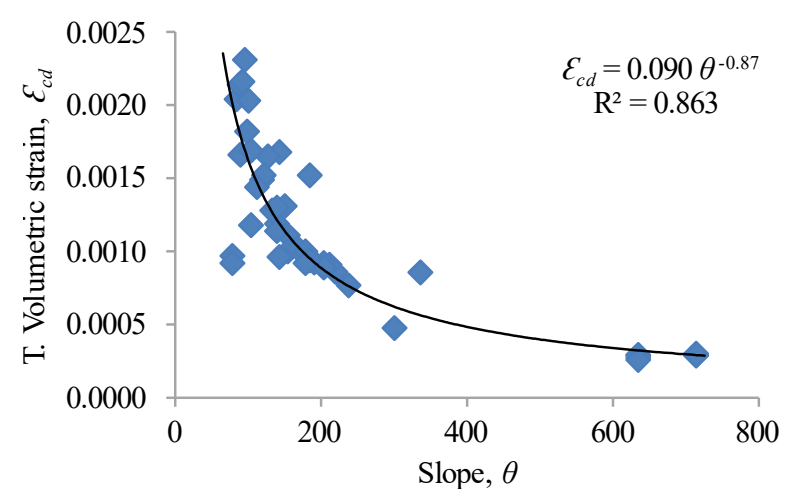

Figure 11. Maximum total volumetric strain and slope for type 2 volumetric strain curve

The coefficient of correlation increases from type one to type two and type three volumetric strain curves, $0.749,0.863$ and 0.952 respectively (Figs. $10-12$ ). The relationship with the different types of volumetric strain curves are described as $\varepsilon_{c d}=0.026 \theta^{-0.62}, \varepsilon_{c d}=0.090^{-0.87}$ and $\varepsilon_{c d}=0.144 \theta^{-0.95}$ for type one to type two and type three respectively. 


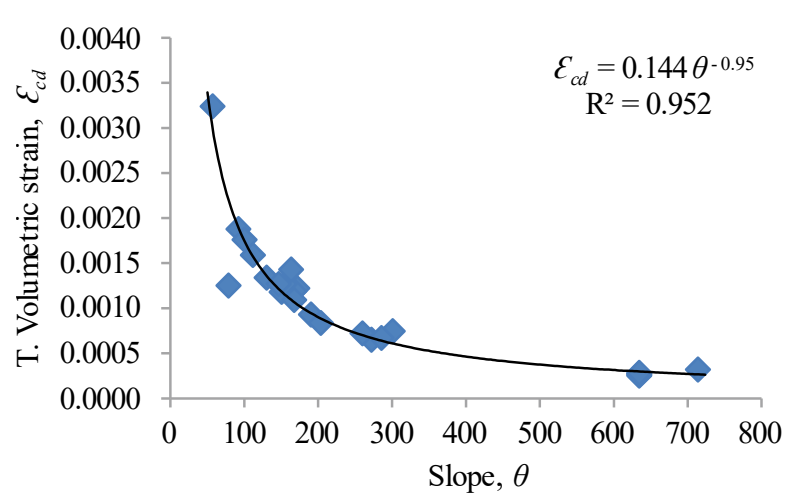

Figure 12. Maximum total volumetric strain and slope for type 3 volumetric strain curve

The constants or coefficient of the equations can be termed as the "coefficient of volumetric strain stiffness moduli". The ratios of the "coefficient of the volumetric strain stiffness modulus" for type one to type two and type three volumetric strain curves are 1:3.5:5.5 respectively. This "coefficient of volumetric strain stiffness modulus" increases from type one to type two and type three of volumetric strain curves respectively.

Similarly, the elastic volumetric strain is related with the slope of normalised stress-total volumetric strain curve by power form function. The curvature of the concave curve get deeper and closer to the $X-Y$ axis as the volumetric strain curves changes from type one to type two and type three respectively. The coefficient of correlation increases from type one to type two and type three volumetric strain curves, $0.581,0.811$ and 0.943 respectively (Figs. $13-15$ ).

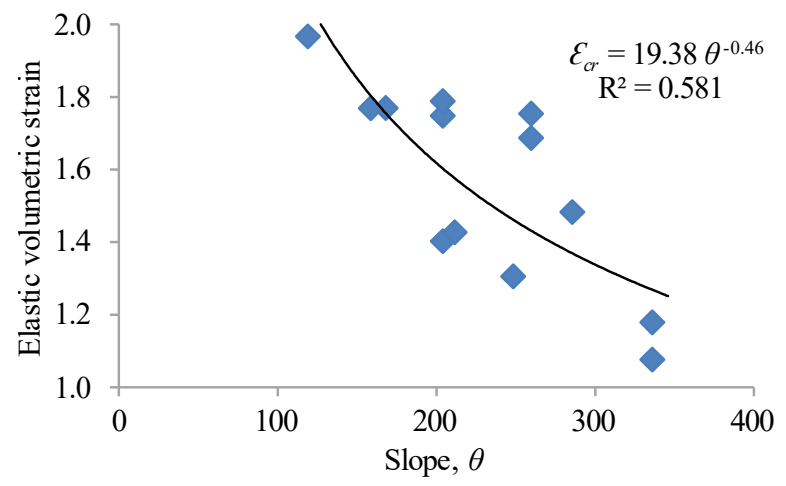

Figure 13. Elastic volumetric strain and slope for type 1 volumetric strain curve

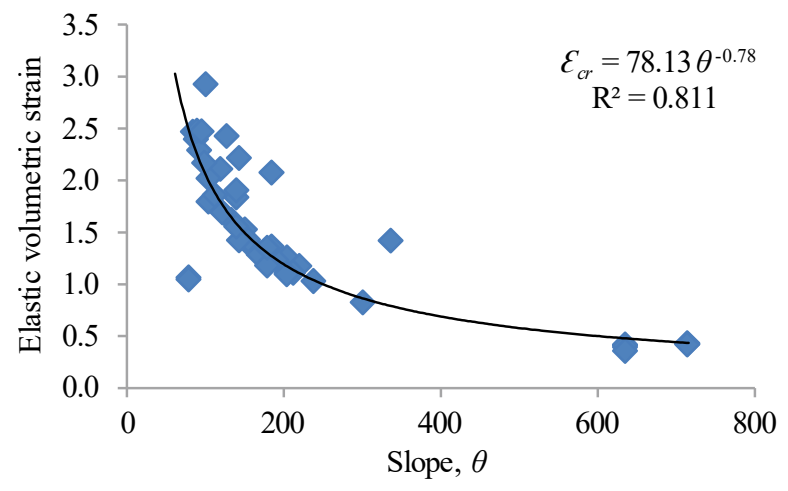

Figure 14. Elastic volumetric strain and slope for type 2 volumetric strain curve

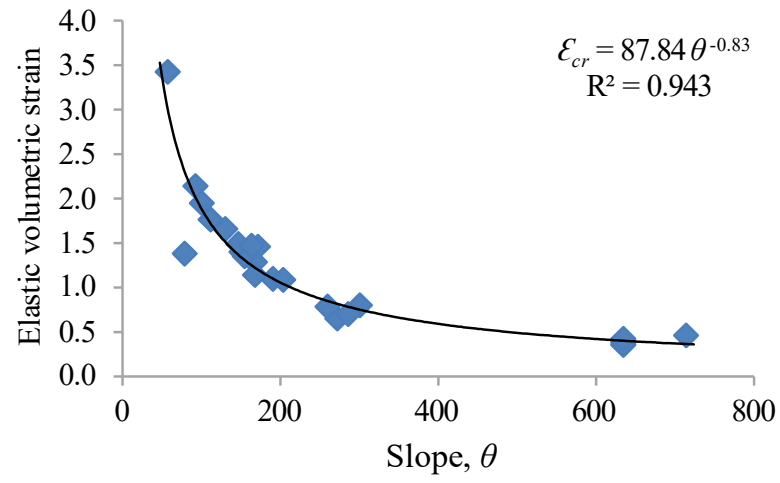

Figure 15. Elastic volumetric strain and slope for type 3 volumetric strain curve

The relationship of the volumetric strain quantities with the different types of volumetric strain curves are described as $\varepsilon_{c r}=19.38 \theta^{-0.46}, \varepsilon_{c r}=78.13 \theta^{-0.78}$ and $\varepsilon_{c r}=87.84 \theta^{-0.83}$ respectively. The ratios of the "coefficient of the volumetric strain stiffness modulus" for type one to type two and type three volumetric strain curves are 1:4.0:4.5 for type one: type two: type three volumetric strain curves respectively. The ratios increase from type one to type two and type three volumetric strain curves respectively.

The elastic volumetric strain is related with the maximum total volumetric strain for type one to type two and type three volumetric strain curves by power form function. The elastic volumetric strain is related with the maximum total volumetric strains linearly but power form law show slightly higher correlation. The coefficient of correlations increases from type one to type two and type three of volumetric strain curves, $0.764,0.966$ and 0.983 respectively (Figs. $16-18$ ).

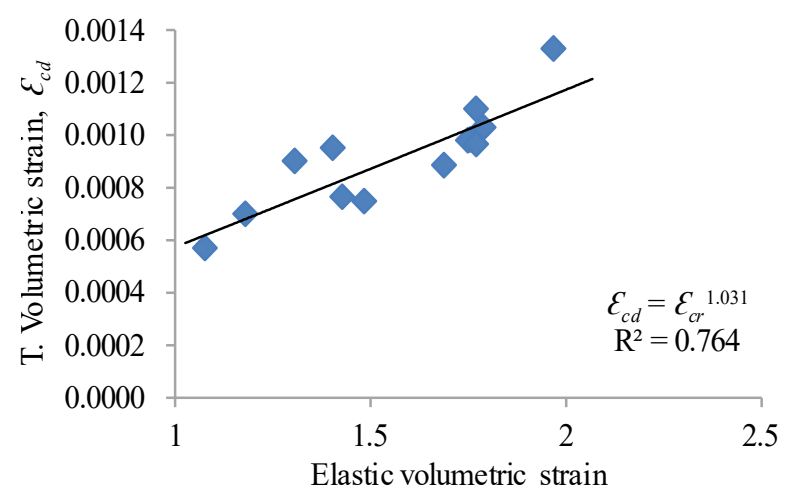

Figure 16. Maximum total volumetric strain and calculated volumetric crack for type 1 volumetric strain curve

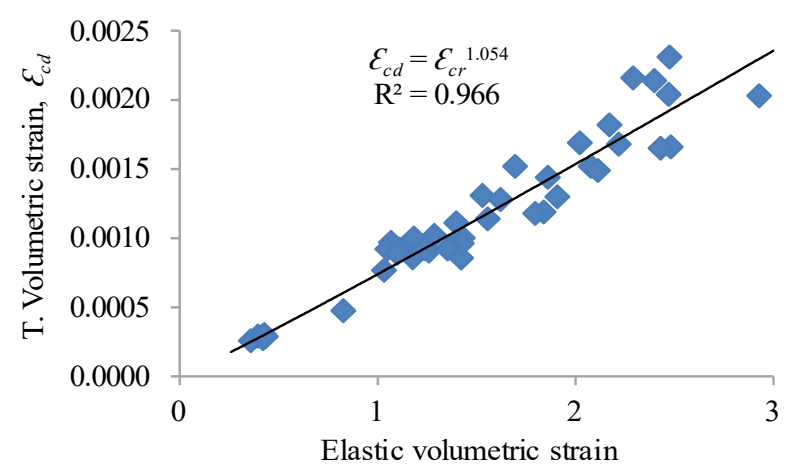

Figure 17. Maximum total volumetric strain and calculated volumetric crack for type 2 volumetric strain curve 


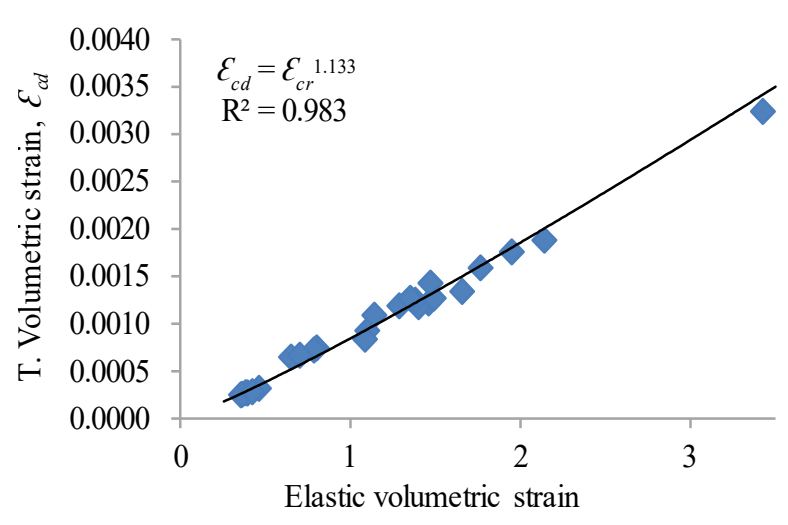

Figure 18. Maximum total volumetric strain and calculated volumetric crack for type 3 volumetric strain curve

The relationship with the different types of volumetric strain curves are described as $\varepsilon_{c d}=\varepsilon_{c r}^{1.031}$; $\varepsilon_{c d}=\varepsilon_{c r}{ }^{1.054}$ and $\varepsilon_{c d}=\varepsilon_{c r}{ }^{1.054}$ respectively.

\section{CONCLUSIONS}

This research work has demonstrated that volumetric strain quantities are related with each other and also separately related with the types of the volumetric strain curves grouped as type one, type two and type three by power form functions. In all cases the coefficient of correlation between the volumetric strain quantities and types of volumetric strain curves increases from type one to type two and type three volumetric strain curves respectively. The type one volumetric strain curve are Class I rocks while type two and type three contained Class II rocks types. The type one is ductile or less brittle while the type two and type three are brittle and very brittle respectively under axial loading condition. The difficulty in obtaining the post-failure curves increases as the total volumetric strain approaches a positive value. In other words, difficulty in obtaining the post-failure curves increases from the first type to the second type and finally the third type.

\section{ACKNOWLEDGEMENTS}

We appreciated Rock Engineering Department, Aalto University Helsinkin Finland for granting permission to determine the post-failure curves of the samples using their closed-loop servo-controlled machine.

\section{REFERENCES}

Akinbinu, V.A. (2016). Class I and Class II Rocks: Implication of Self-sustaining Fracturing in Brittle Compression. Geotechnical and Geological Engineering, 34(3), 877-887. https://doi.org/10.1007/s10706-016-0011-0

Akinbinu, V.A. (2017). Relationship of Brittleness and Fragmentation in Brittle Compression. Engineering Geology, (221), 82-90.

https://doi.org/10.1016/j.enggeo.2017.02.029

Bieniawski, Z.T. (1967a). Stability Concept of Brittle Fracture Propagation in Rock. Engineering Geology, 2(3), 149-162. https://doi.org/10.1016/0013-7952(67)90014-2

Bieniawski, Z.T. (1967b). Mechanism of Brittle Fracture of Rock: Part II - Experimental Studies. International Journal of Rock Mechanics and Mining Sciences \& Geomechanics Abstracts, 4(4), 407-423. https://doi.org/10.1016/0148-9062(67)90031-9
Bieniawski, Z.T. (1967c). Mechanism of Brittle Fracture of Rock: Part I - Theory of the Fracture Process. International Journal of Rock Mechanics and Mining Sciences \& Geomechanics Abstracts, 4(4), 395-406. https://doi.org/10.1016/0148-9062(67)90030-7

Brace, W.F., Paulding, B.W., \& Scholz, C. (1966). Dilatancy in the Fracture of Crystalline Rocks. Journal of Geophysical Research, 71(16), 3939-3953. https://doi.org/10.1029/jz071i016p03939

Cai, M., Kaiser, P., Tasaka, Y., Maejima, T., Morioka, H., \& Minami, M. (2004). Generalized Crack Initiation and Crack Damage Stress Thresholds of Brittle Rock Masses Near Underground Excavations. International Journal of Rock Mechanics and Mining Sciences, 41(5), 833-847. https://doi.org/10.1016/j.ijrmms.2004.02.001

Craggs, J.W. (1960). On the Propagation of a Crack in an Elastic-Brittle Material. Journal of the Mechanics and Physics of Solids, 8(1), 66-75. https://doi.org/10.1016/0022-5096(60)90006-5

Eberhardt, E., Stead, D., \& Szczepanik, Z. (1998). Crack Initiation and Propagation in Granite and Granodiorite from the $130 \mathrm{~m}$ and $420 \mathrm{~m}$ Levels of the URL. Report No.AECL 122567. Manitoba, Canada: Atomic Energy of Canada Limited.

Pérez Hidalgo, K., \& Nordlund, E. (2013). Comparison Between Stress and Strain Quantities of the FailureDeformation Process of Fennoscandian Hard Rocks Using Geological Information. Rock Mechanics and Rock Engineering, 46(1), 41-51. https://doi.org/10.1007/s00603-012-0242-1

Ulusay, R. (2015). The ISRM Suggested Methods for Rock Characterization, Testing and Monitoring: 2007-2014. Ankara, Turkey: Pergamum Press Ltd. https://doi.org/10.1007/978-3-319-07713-0

Katz, O., \& Reches, Z. (2004). Microfracturing, Damage, and Failure of Brittle Granites. Journal of Geophysical Research: Solid Earth, 109(B1). https://doi.org/10.1029/2002jb001961

Kemeny, J., \& Cook, N.G.W. (1986). Effective Moduli, NonLinear Deformation and Strength of a Cracked Elastic Solid. International Journal of Rock Mechanics and Mining Sciences \& Geomechanics Abstracts, 23(2), 107-118. https://doi.org/10.1016/0148-9062(86)90337-2

Kim, J.S., Lee, K.S., Cho, W.J., Choi, H.J., \& Cho, G.C (2015). A Comparative Evaluation of Stress-Strain and Acoustic Emission Methods for Quantitative Damage Assessments of Brittle Rock. Rock Mechanics and Rock Engineering, 48(2), 495-508. https://doi.org/10.1007/s00603-014-0590-0

Lau, J.S.O., \& Chandler, N.A. (2004). Innovative Laboratory Testing. International Journal of Rock Mechanics and Mining Sciences, 41(8), 1427-1445. https://doi.org/10.1016/j.ijrmms.2004.09.008

Martin, C.D. (1993). The Strength of Massive Lac du Bonnet Granite Around Underground Openings. PhD Thesis. Winnipeg, Canada: University of Manitoba

Martin, C.D., \& Chandler, N.A. (1994). The Progressive Fracture of Lac du Bonnet Granite. International Journal of Rock Mechanics and Mining Sciences \& Geomechanics Abstracts, 31(6), 643-659. https://doi.org/10.1016/0148-9062(94)90005-1

Palchik, V. (2009). Mechanical Behavior of Carbonate Rocks at Crack Damage Stress Equal to Uniaxial Compressive Strength. Rock Mechanics and Rock Engineering, 43(4), 497-503. https://doi.org/10.1007/s00603-009-0042-4

Palchik, V., \& Hatzor, Y.H. (2002). Crack Damage Stress as a Composite Function of Porosity and Elastic Matrix Stiffness in Dolomites and Limestones. Engineering Geology, 63(3-4), 233-245. https://doi.org/10.1016/s0013-7952(01)00084-9 
Qiaoxing, L. (2006). Strength Degradation and Damage Micromechanism of Granite Under Long-Term Loading. PhD Thesis. Hong Kong, China: University of Hong Kong.

Stefanov, Y.P., Chertov, M.A., Aidagulov, G.R., \& Myasnikov, A.V. (2011). Dynamics of Inelastic Deformation of Porous Rocks and Formation of Localized Compaction Zones Studied by Numerical Modeling. Journal of the Mechanics and Physics of Solids, 59(11), 2323-2340.

https://doi.org/10.1016/j.jmps.2011.08.002
Wawersik, W.R., \& Fairhurst, C. (1970). A Study of Brittle Rock Fracture in Laboratory Compression Experiments. International Journal of Rock Mechanics and Mining Sciences \& Geomechanics Abstracts, 7(5), 561-575. https://doi.org/10.1016/0148-9062(70)90007-0

\section{ОЦІККА ВЕЛИЧИН ОБ'ЄМНОЇ ДЕФОРМАЦІЇ ТА ТИПІВ КРИВИХ, ЩО ЇЇ ОПИСУЮТЬ, ПРИ ДЕФОРМАЦІЇ ТА РУЙНУВАННІ ТВЕРДИХ КРИХКИХ ПОРІД}

\section{В.А. Акінбіну, Е.О. Аджака, Д.Дж. Афу}

Мета. Встановлення та оцінка взаємозв'язку між різними величинами та типами кривих об'ємної деформації у процесі одноосьового стиску жорстких крихких порід.

Методика. Повні криві напруження й деформації визначалися при необмеженому одноосьовому випробуванні на стиск з використанням системи сервокерованого контролю із замкнутим контуром для оцінки механічних властивостей 83 різних типів порід (53 вивержених, 10 осадових і 20 метаморфічних). Процедури випробувань для визначення повних кривих напружень і деформацій гірських порід, а також параметрів їх міцності проводилися відповідно до запропонованого ISRM методу.

Результати. Дослідження показали, що залежність величин об'ємної деформації описується степеневим законом. Встановлено, що існує зв'язок між величинами об'ємної деформації та типами кривих, що ії описують. Перший тип кривих об'ємної деформації відповідає породам класу I з переходом до класу II, у той час як криві третього типу повністю відповідають породам класу II.

Наукова новизна. Вперше експериментальним шляхом встановлено взаємозв'язок між типами кривих об’ємної деформації та її величиною. Зроблені перші спроби пов'язати величину об’ємної деформації з кривими напруження - деформації порід після руйнування при одноосьовому стиску, у той час як попередні результати отримані під час стиску.

Практична значимість. Складність отримання кривих для стану породи після руйнування збільшується 3 переходом від 1 типу кривих об'ємної деформації до 2 і 3 типу, що є важливим аспектом для безпечного тестування порід персоналом. Результати роботи представляють інтерес для розуміння загальних процесів деформації зразка та оцінки крихкості порід (наприклад, крихкі породи класу II і менш крихкі або більш пластичні породи класу I).

Ключові слова: криві стану після руйнування, процес деформаиії, еластична об'ємна деформаиія, крива об'ємної деформачії, загальна максимальна об'ємна деформаџія, крихкі породи

\section{ОЩЕНКА ВЕЛИЧИН ОБЪЕМНОЙ ДЕФОРМАЦИИ И ТИПОВ ОПИСЫВАЮЩИХ ЕЕ КРИВЫХ ПРИ ДЕФОРМАЦИИ И РАЗРУШЕНИИ ТВЕРДЫХ ХРУПКИХ ПОРОД}

\section{В.А. Акинбину, Э.О. Аджака, Д.Дж. Афу}

Цель. Установление и оценка взаимосвязи между различными величинами и типами кривых объемной деформации в процессе одноосного сжатия жестких хрупких пород.

Методика. Полные кривые напряжения и деформации определялись при неограниченном одноосном испытании на сжатие с использованием системы сервоуправляемого контроля с замкнутым контуром для оценки механических свойств 83 различных типов пород (53 изверженных, 10 осадочных и 20 метаморфических). Процедуры испытаний для определения полных кривых напряжений и деформаций горных пород, а также параметров их прочности проводились в соответствии с предложенным ISRM методом.

Результаты. Исследование показали, что зависимость величин объемной деформации описывается степенным законом. Установлено, что существует связь между величинами объемной деформации и типами описывающих ее кривых. Первый тип кривых объемной деформации соответствует породам класса I с переходом к классу II, в то время как кривые третьего типа полностью соответствуют породам класса II.

Научная новизна. Впервые экспериментальным путем установлена взаимосвязь между типами кривых объемной деформации и ее величиной. Предприняты первые попытки связать величину объемной деформации с кривыми напряжения - деформации пород после разрушения при одноосном сжатии, в то время как предыдущие результаты получены во время сжатия.

Практическая значимость. Сложность получения кривых для состояния породы после разрушения увеличивается по мере перехода от 1 типа кривых объемной деформации ко 2 и 3 типу, что является важным аспектом для безопасного тестирования пород персоналом. Результаты работы представляют интерес для понимания общих процессов деформации образца и оценки хрупкости пород (например, хрупкие породы класса II и менее хрупкие или более пластичные породы класса I).

Ключевые слова: кривые состояния после разрушения, прочесс деформачии, эластичная объемная деформация, кривая объемной деформачии, общая максимальная объемная деформаџия, хрупкие породы 


\section{ARTICLE INFO}

Received: 6 January 2018

Accepted: 18 November 2018

Available online: 8 December 2018

\section{ABOUT AUTHORS}

Victor Abioye Akinbinu, Doctor of Philosophy, Senior Lecturer of the Department of Mining Engineering, Federal University of Technology Akure, Ilesha-Akure Expressway, P.M.B. 704, Akure, Ondo State, Nigeria. E-mail: akinbinuvictor@gmail.com

Ebenezer Oyedele Ajaka, Doctor of Philosophy, Associate Professor of the Department of Mining Engineering, Federal University of Technology Akure, Ilesha-Akure Expressway, P.M.B.704, Akure, Ondo State, Nigeria. E-mail: eoajaka@futa.edu.ng

Damilola Johnson Afu, Master of Sciences, Senior Lecturer of the Department of Mining Engineering, Federal University of Technology Akure, Ilesha-Akure Expressway, P.M.B. 704, Akure, Ondo State, Nigeria. E-mail: djafu@,futa.edu.ng 